Article

\title{
Open Innovation and Competitive Advantage on the Hospitality Sector: The Role of Organizational Strategy
}

\author{
Francisco Musiello-Neto ${ }^{1}$, Orlando Lima Rua ${ }^{2,3, *}$, Mario Arias-Oliva ${ }^{1,4}$ (D) and Amélia Ferreira Silva ${ }^{2}$ (D) \\ 1 Department of Business Management, University of Rovira i Virgili, 43002 Tarragona, Spain; \\ musiello@mail.uft.edu.br (F.M.-N.); mario.arias@urv.cat or mario.arias@ucm.es (M.A.-O.) \\ 2 Center for Organisational and Social Studies (CEOS.PP), Porto School of Accounting and Business (ISCAP), \\ Polytechnic of Porto (P.PORTO), 4465-004 S. Mamede de Infesta, Portugal; acfs@iscap.ipp.pt \\ 3 Research Center of Business Sciences (NECE), University of Beira Interior (UBI), 6200-209 Covilhã, Portugal \\ 4 Department of Management and Marketing, Complutense University of Madrid, 28040 Madrid, Spain \\ * Correspondence: orua@iscap.ipp.pt
}

Citation: Musiello-Neto, F.;

Rua, O.L.; Arias-Oliva, M.; Silva, A.F. Open Innovation and Competitive Advantage on the Hospitality Sector: The Role of Organizational Strategy. Sustainability 2021, 13, 13650. https:/ / doi.org/10.3390/su132413650

Academic Editors: Beatriz Forés Julián and César Camisón

Received: 18 October 2021

Accepted: 3 December 2021

Published: 10 December 2021

Publisher's Note: MDPI stays neutral with regard to jurisdictional claims in published maps and institutional affiliations.

Copyright: (c) 2021 by the authors. Licensee MDPI, Basel, Switzerland. This article is an open access article distributed under the terms and conditions of the Creative Commons Attribution (CC BY) license (https:// creativecommons.org/licenses/by/ $4.0 /)$.

\begin{abstract}
This paper assesses the relationship between open innovation and competitive advantage and the mediating effect of organizational strategy. Using a quantitative methodological approach with survey data from 251 Portuguese hotel executive directors' small and medium-sized enterprises (SMEs), this research adopted a quantitative methodological approach, thereby conducting an exploratory and transversal study. Findings show that (1) open innovation influences organizational strategy and (2) organizational strategy enhances competitive advantage. Moreover, the results also highlight that (3) organizational strategy has a mediating effect between open innovation and competitive advantage. The paper provides relevant insights that will lead the firms' top managers to design and implement strategies and define effective government policies, programs, and incentives to support the development of the firms' open innovation model in the hospitality sector considering the new smart society and smart cities growing environment.
\end{abstract}

Keywords: open innovation; competitive advantage; organizational strategy; hospitality sector; structural equations model

\section{Introduction}

Open innovation became an increasingly established topic in the management literature since the beginning of this century [1], with the impact of the open innovation management model currently a topic of significant discussion within academia [2]. For Aranha et al. [3], the recent considerable research on open innovation does not reflect robustness in the concept, which still needs understanding and deepening of the principles of open innovation aimed at SMEs, usually organizations that present more significant restrictions in its implementation. Smith [4] recognizes the evolution of open innovation in its various forms but concludes that further discussions are needed for its understanding and implementation due to few academic studies, mainly about SMEs.

The innovation management literature has developed solid prior knowledge that has given rise to open innovation, antagonistic to closed innovation, with the contribution of R\&D outsourcing, i.e., outsourcing, inter-firm collaboration, and organization-environment interaction [5]. Open innovation thus emerges as an emerging paradigm to replace the previous paradigm, defined by Chesbrough [6] as closed innovation. As a strategy of different management models, the role of open innovation aims to obtain a competitive advantage by organizations [7]. For this purpose, strategic positioning tends to identify key factors for recognizing opportunities and making decisions that affect organizational processes [8]. The development of innovative products by organizations derives from the openness to external knowledge [9-11]. 
The firms' management competence depends on the ability of top managers to mobilize and distribute available resources, which includes knowledge about the development of business ecosystems (suppliers, customers, and other stakeholders) that enhance the creation of organizational value [12]. This capacity reflects, in a positive way, (1) the results achieved by firms by leveraging their value chains, with strategic business objectives aligned through management innovation [13], and (2) the intentional use of knowledge to promote internal innovation and to develop markets, taking on the contours of the paradigm of closed innovation [9]. In this context, SMEs top managers' practices are particularly vital to verify if there is an effective relationship between the activities of management innovation, since the boundaries of organizations are increasingly permeable to competition and its influencing environments and technological developments, with an increasing tendency to the interconnection of people, solutions, and organizations [14].

Firms seek answers in business environments marked by uncertainty and vulnerability. In this sense, top managers must have the flexible and diversified capacity to overcome market instability and thus promote adaptation to competitive markets. These organizations use integrated business strategies as a compass to guide themselves in the face of business competition [15]. Inclusively, Fayoumi and Loucopoulos [16] maintain that organizations have various business languages seeking to meet particular business' variables (e.g., goals, decisions, rules, processes, and organizational structure, etc.) to boost possible profitable returns on their investment. These market dynamics accelerate the intensification of competition and create new solutions for products, processes, shorter product and service life cycles, flexibility for market service, new inputs, and changes in production organization patterns) [17]. These elements configure the so-called new competition (open innovation). Thus, with associated vulnerability and uncertainty, market dynamics concern the business model of open innovation, recreating a collaborative and partnership environment with research and development (R\&D) institutions to develop and commercialize intellectual property and create economic value to the organization [18,19]. Therefore, for Weiblen [19], the term "open" is linked with a firm's collaborative ecosystem. This linkage is oriented toward the model's design in which strategic decisions focus on value creation, making it essential to manage the execution risk of R\&D projects.

Managers identify and develop new ideas to build, support, and stimulate employees involved in learning and processes. This framework contributes to the efficiency and coordination of existing capabilities, which support new organizational capabilities and gain competitiveness, as each leadership style contributes to the transformational competencies of the firm [20]. Thus, this paper aims to investigate the effect of open innovation in competitive advantage by examining the mediating effect of organizational strategy by addressing the following research questions: Does open innovation have a positive effect on competitive advantage? Additionally, does organizational strategy mediate the relationship between open innovation and competitive advantage?

This paper is organized as follows: First, the theoretical foundations for this study are presented, leading to the hypotheses' development and proposed model. In the following section, we put forward the methodology, including the research design and measures. Then, results are analyzed. Finally, we discuss these results and present our conclusions.

\section{Theoretical Framework}

\subsection{Open Innovation}

The concept of the open innovation model is not completely new [21,22]. Cohen and Levinthal [23] previously developed the concept of absorptive capabilities, i.e., the ability of firms to recognize the importance of external information that, after an assimilation process, can be applied to valuable, marketable products. Besides, these researchers had already explored the relationship between innovation and dynamic capabilities, mainly a firm's ability to interact, develop, and define internal and external capabilities in competitive environments. For Teece et al. [24], it translates into exploring new possibilities originating in exploiting old certainties (closed innovation) related to organizational learn- 
ing. According to Chesbrough [6] (p. 24), this leads to the emergence of open innovation, characterized as something that "embraces, connects and integrates a range of existing activities," defined as "a paradigm that assumes that companies can and should use both external and internal ideas, and internal and external paths to market as companies seek to advance their technology". Following the consolidation of the open innovation concept, intentional knowledge inputs and outputs can boost internal innovation and enhance external innovation on complex markets [9]. For Lichtenthaler [25] (p. 77), open innovation allows "systematically realizing the exploration, retention, and exploitation of knowledge within and outside the boundaries of an organization throughout the innovation process".

Chesbrough and Bogers [22] argue that the concept of open innovation proposes that the R\&D model is transformed into knowledge inputs and outputs that they can manage purposefully, where firms can (1) develop input processes to seek and transfer external knowledge for their innovation activities, (2) create output channels to move new internal knowledge within the firm to other organizations in the surrounding environment, and (3) define specific mechanisms designed to direct these knowledge inputs and outputs. The open innovation model defines requirements of the relationship between innovation and organizational processes, which generates new internal and external ideas and allows the formation of a new architecture, systems, and management platforms [26]. In addition to providing guidelines, management is responsible for delivering the active support needed to manage the change in business processes that new technologies impact, which facilitates the mitigation of stakeholders' resilience and increases the chances of success [27].

However, for Chesbrough and Crowther [9], factors such as organizational culture, the role of the top manager (innovation process), intellectual capital (employee talent), and organizational structures have begun to be reviewed based on the concept of open innovation. Firms seeking to structure or remodel new management processes will need to deal with a greater flow of ideas from various sources outside the corporation. For Van De Vrande et al. [28] and Huizingh [2], some activities favor the firm in acquiring new knowledge and technologies outside the boundaries of the organization (e.g., partnerships), allowing an intentional flow of knowledge input that will capture and benefit from external sources of knowledge. According to these authors, partnerships can also evolve into formal alliances or the acquisition of technological capabilities to (i) establish external participations by investing in start-ups to maintain market opportunities, (ii) outsource R\&D to acquire external, licensed, or purchased knowledge, and (iii) bring in key knowledge developed outside the boundaries of the organization.

Open innovation enables the acquisition of new inter-organizational competencies by offering a perspective for developing dynamic capabilities [24]. The promotion of knowledge for managing success or failure and competence as a transition from the management process complement each other, as organizations of different branches and sizes can benefit from open innovation, even when they are not the developers of new products, services, and technologies [24].

Thus, it is intended to test the following research hypothesis:

Hypothesis 1 (H1). Open innovation has a positive effect on organizational strategy.

\subsection{Organizational Strategy}

Firms need to create a heterogeneity that enhances exploiting resources and implementing innovation strategies [29]. The implications and consequences of implementing organizational strategies increasingly focus on the human factor, the management of new knowledge, and best practices to expand business [30]. Therefore, there seems to be a reasonable degree of consensus on the effectiveness of the strategy concept and its implications as a guide for long-term organizational management [31,32].

In dealing with the challenges of the organizational environment, firms must strengthen their R\&D capabilities and promote innovative cultures and work teams [33]. This way, service firms should design the refined categorization of technological innovation to aid business renewal with new marketing approaches, new management practices (structural 
or technical), and new work processes, thus developing innovative forms of employee management that foster internal and external relations [34]. Technological advances, such as the internet, transportation, logistics, and materials, etc., have changed firms' performance and generated many new companies with new businesses and new business models, where these technologies certainly influence the expectations and dissemination of "new technologies" [35].

The organizational strategy concentrates the resources to achieve the desired results; strategy drives organizational practices and decisions associated with allocating resources and seeking opportunities [36]. However, Spyropoulou et al. [37] argue that there is a need to align organizational characteristics with competitive strategy and managerial risk mechanisms to build management to achieve superior performance. There are significant interactions between organizational characteristics (decision-making style, organizational structure, and management style) and the strategies employed by organizations [38]. Management mechanisms facilitate alignment between technology and business strategies, thus establishing a market orientation that significantly affects organizational innovation [39].

Any competitor cannot simultaneously implement a strategy that leads the organization to a competitive advantage [40-42]. Organizations launch innovative products to achieve sustainable competitive advantage [43]. The linkage between innovation and competitive advantage allows the organization to effectively use its resources (internal and external) to manage them for the generation of innovations, which are likely to gain a competitive advantage. However, Nuryakin [44] argues that market orientation for product and service innovation is empirical evidence on the importance of competitive advantage to enhance superior performance in SMEs by top managers.

This leads us to posit the following hypothesis:

Hypothesis 2 (H2). Organizational strategy positively influences competitive advantage.

\subsection{Competitive Advantage}

For Porter [45], competitive advantage is gained when a firm adds value for customers; it is not just about production cost-it is also about market solutions that competitors cannot deliver, and it must accomplish a firm's position or its market leadership. Firms can thus take advantage of their capabilities and competencies to promote business growth and gain competitive advantages $[46,47]$. The author mentions the example of developed countries; as a result, they are more competitive than others (developing countries), by using internal productive capacities and structures capable of transforming into competitive advantages, something that companies from these (developing) countries cannot. This author also identifies two sources of competitive advantage for the organization. The first refers to the lower production cost achieved by the firm, which provides greater productivity by marketing its product more effectively and choosing more competitive prices. The second refers to the differentiation of products and services, the ability to offer the customer a superior final value product or service in terms of product quality, specific features, and/or support services. According to Porter [46,47], these sources are embedded in the competitive process, directly implying the creation of competitive advantages and their long-term sustainability.

However, Barney [48] and Rua [49] mentions that the firm must consider the available resources that can be the differential for the construction and consolidation of the market. Thus, a competitive advantage is accomplished when an organizational strategy can create innovative products for the customer. Therefore, the most significant opportunities for value creation are being seized by retail chains; these are decisive for improving the quality of the firm's products and services and maintaining competitive advantage [50,51]. For Simão and Franco [52], the difference between the firm's product or service with its competitors should be durably grounded in the market. Analyzing the impact of different sources of knowledge (internal and external) for organizational innovation adoption and decision making can stimulate the introduction of new management practices because external sources are the main drivers for innovative ideas [48]. 
Hong et al. [53] maintain that open innovation can positively influence competitive advantage as available organizational resources are essential for better performance in the organization. Innovative firms' introduction of unique products or services allows them to be more competitive and successful than their competitors [54]. Innovative firms can convert competitive threats into opportunities by delivering differentiated products or services; innovative firms are increasingly globalized and segmented market-oriented than in minimally competitive markets [55,56]. For Wang and Wu [57], resources only become significant when they are abundant.

Thus, we intend to empirical test the following hypotheses:

Hypothesis 3 (H3). Open innovation has a positive effect on competitive advantage.

Hypothesis 4 (H4). Organizational strategy has a mediating effect on the relationship between open innovation and competitive advantage.

Figure 1 presents the proposed research model and hypotheses.

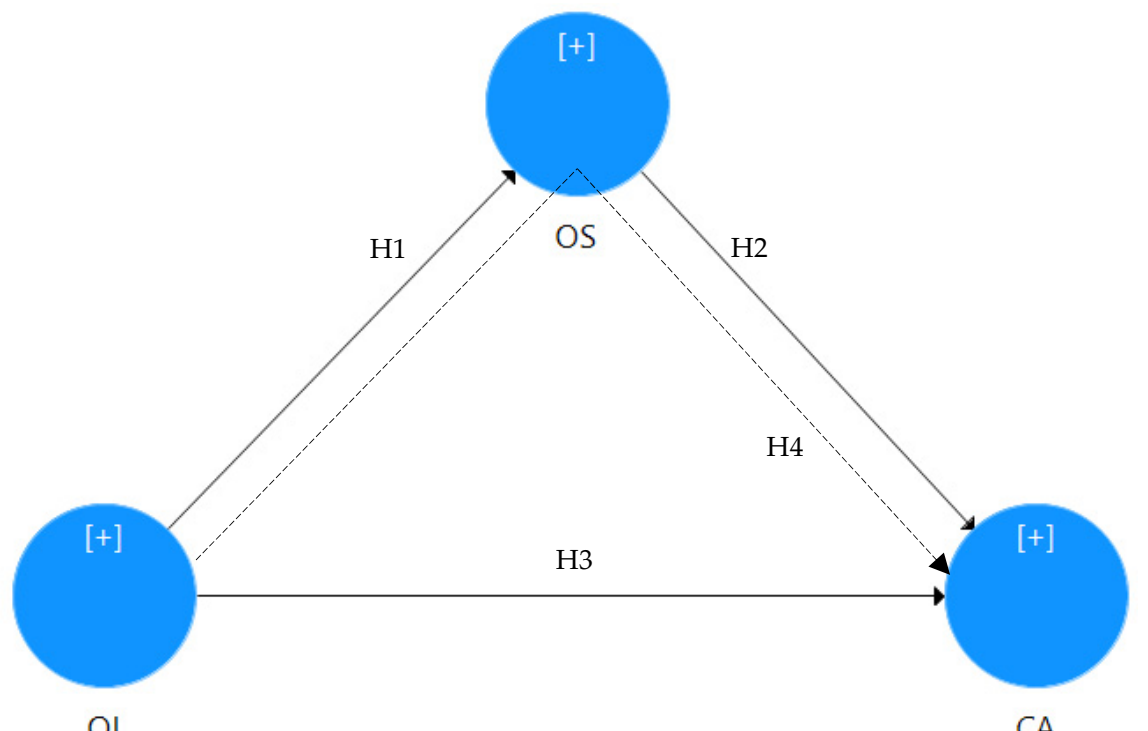

Figure 1. Research model and hypotheses. Notes: OI-Open Innovation; OS-Organizational Strategy; CA-Competitive Advantage. Source: Own elaboration.

\section{Research Methods}

\subsection{Sample Design and Data Collection}

The sample was drawn from Portuguese hospitality sector firms. A questionnaire was used as the primary data source and was carried out from 28 October 2018 to 27 April 2019. The identification of firms was made through Portugal's Hotel, Restaurant and Similars Association (Associação da Hoteleira, Restauração e Similares de Portugal—AHRESP) database, which features 1727 hotels, of which 717 were disregarded for not having active e-mail. Thus, in this study, we have used non-probabilistic and convenient sampling.

Hotel executive directors were the elements of research, and the unit of analysis is individual. 348 responses were received, of which 97 were eliminated because (1) the survey was not fully covered, (2) the hotel had no employee designated for this purpose, and/or (3) the manager did not have time to respond to the survey. Thus, 251 complete and validated questionnaires were obtained, and the sample size was considered appropriate according to Krejcie et al. [58]. This score corresponds to a response rate of $24.85 \%$, which is regarded as good as the average response rate of the top management survey is in the range of $15-20 \%$ [59]. According to Hair et al. [60], this sample size is considered suitable for data analysis using structural equation modeling of partial square composition (PLS-SEM), as it allows analysis even with small sample sizes. 


\subsection{Measures}

The constructs of this study were measured with scales from previous research. The two dimensions of open innovation, inbound and outbound, were assessed using 6 items from Sisodiya et al. [61] and 5 items from Cheng and Huizingh [62]. The three dimensions of organizational strategy, environmental dynamism, organization structure, and strategic posture, were measured using the 21 items proposed by Morgan et al. [63]. The three dimensions of competitive advantage, cost, service, and product were analyzed according to the 10 items recommended by Kaleka et al. [64]. All items are presented in Appendix A.

We followed Brislin's [65] recommendations when translating the questionnaire from English into Portuguese. The two versions were compared to avoid any discrepancies and differences between the two. This process was ensured by the Porto School of Accounting and Business (Portugal).

\section{Results}

\subsection{Non-Response Bias and Common Method Bias}

We tested the non-responses bias to verify whether the responses obtained reflect whether the sample is representative of the population. Thus, we used the extrapolation method suggested by Armstrong and Overton [66] to test the non-existence of differences between two groups of respondents, the group of early respondents (first quartile), and the group of later respondents (fourth quartile). For these authors, the responses of non-respondents are similar to those of the last respondents. The second group is considered representative of the population if there are no significant differences between these two groups. The response dates of the elements of the first group are between 28 October and 31 December 2018 ( 82 responses) and the second group between 1 January and 27 April 2019 (169 responses). We compared the first answers (first quartile) with the last answers (fourth quartile).

To assess differences between groups, we compared the means of responses obtained for respondents in the first group (first quartile) and the second group (fourth quartile) for all variables included in the model. For this purpose, the Mann-Whitney $U$ test was used, which showed that most of the means of the later responses are higher than the means of the initial responses. Still, the differences are not statistically significant $(p>0.05)$, so the null hypothesis of equality of means between the initial and later answers. We then conclude that the sample is representative of the population.

Ten specialists validated the instrument's content-five executive directors and five professors specialized in hotel management. A pilot study was carried out by sending the questionnaire to 32 executive directors of hotels to ensure its clarity. This process did not lead to amendments to the questionnaire. Reliability was also assessed to verify the internal consistency of the scales used in the study, which proved to be excellent (0.934).

\subsection{Descriptive Analysis}

The reliability analysis was performed using Cronbach's alpha. It is possible to sustain the responses' consistency, stability, and heterogeneity, according to Pestana and Gageiro [67]. The sample reliability is excellent for all variables (0.958).

Table 1 shows the descriptive statistics of the sample's demographics.

\subsection{Partial Least Square Structural Equations Modeling (PLS-SEM)}

PLS-SEM path modeling was used to test our hypotheses $[60,68]$. This technique is the most adequate to estimate our research model since: (1) this study focuses on prediction and explanation of constructs variance (in our case, three), and (2) the relationship between open innovation and competitive advantage can be measured directly and indirectly via organizational strategy. 
Table 1. Standardized factor analysis loadings, AVE, and CR.

\begin{tabular}{lc}
\hline \multicolumn{1}{c}{ Item } & $\%$ \\
\hline Gender: & \\
Male & 62.5 \\
Female & 37.5 \\
\hline Age (years old): & \\
$18-25$ & 19.3 \\
$26-35$ & 26.9 \\
$36-45$ & 42.6 \\
$46-55$ & 8.4 \\
$>55$ & 2.8 \\
\hline Academic qualifications: & \\
Vocational qualification & 55.6 \\
Bachelor degree & 28.9 \\
Master degree & 12.6 \\
PhD & 2.9 \\
\hline Professional experience (years): & \\
$<1$ & 7.3 \\
$1-5$ & 48.7 \\
$6-10$ & 30.8 \\
$>10$ & 13.2 \\
\hline
\end{tabular}

\subsection{Results of Measurement Model Assessment}

The reliability of the variables was studied by analyzing the internal stability and consistency of Cronbach's alpha, which must be greater than $0.7[69,70]$. The Cronbach's alpha is excellent, ranging between 0.931 and 0.978 (Table 1) [67]. Results show that the measurement model meets all general requirements. First, all reflective items have a load higher than 0.707 , which means that the reliability of individual indicators (loading) is higher than 0.5 . Second, all-composite reliability values and Cronbach's alpha values are higher than 0.70 , suggesting acceptable model reliability. Third, the average variance extracted (AVE) values of all constructs are higher than 0.50, indicating an adequate convergent validity and implying that our set of indicators represent the same underlying construct [60].

The composite reliability coefficient was also used to test the convergent validity [71]. As can be seen from Table 1, using the parameters of Gefen and Straub [72] that advocate a minimum level of 0.6 , the variables exponentially exceed the required value. In this study, the method proposed by Fornell and Larcker [73] was used, which suggests using the AVE with a minimum value of 0.5 to prove convergent validity. As can be seen in Table 2, all variables did also reach the required value.

Discriminant validity is determined by construct and is related to the level at which it differs and stands out from the other constructs of the model, thus making it necessary to have no correlations with other latent variables, and it can be gauged from the principle that all cross loads cannot be higher than the loading of each indicator [60]. Henseler et al. [74] propose Heterotrait-Monotrait Ratio (HTMT) to assess the discriminant validity, which is a new and advanced criterion and is one of the effective methods to evaluate it. Therefore, HTMT was used to assess the discriminant validity of the constructs, and its values are given in Table 3. All the values were less than 0.90, as recommended by Gold et al. [75]; hence, discriminant validity had also been established for all constructs. 
Table 2. Standardized factor analysis loadings, AVE, and CR.

\begin{tabular}{|c|c|c|c|c|c|c|}
\hline First-Order Constructs & Items & Loadings & CR & AVE & Mean & SD \\
\hline $\begin{array}{l}\text { Open innovation } \\
(\alpha=0.957)\end{array}$ & $\begin{array}{l}\text { OI_9 } \\
\text { OI_10 } \\
\text { OI_3 } \\
\text { OI_2 } \\
\text { OI_5 } \\
\text { OI_8 } \\
\text { OI_4 } \\
\text { OI_7 } \\
\text { OI_6 } \\
\text { OI_11 } \\
\text { OI_1 }\end{array}$ & $\begin{array}{l}0.903 \\
0.897 \\
0.892 \\
0.888 \\
0.884 \\
0.862 \\
0.716 \\
0.698 \\
0.690 \\
0.686 \\
0.635 \\
\end{array}$ & 0.962 & 0.698 & $\begin{array}{l}4.74 \\
4.71 \\
4.84 \\
4.67 \\
4.68 \\
4.84 \\
5.03 \\
4.53 \\
4.65 \\
4.53 \\
5.12 \\
\end{array}$ & $\begin{array}{l}1.482 \\
1.523 \\
1.653 \\
1.666 \\
1.653 \\
1.497 \\
1.535 \\
1.622 \\
1.671 \\
1.621 \\
1.605\end{array}$ \\
\hline $\begin{array}{l}\text { Organizational strategy } \\
(\alpha=0.970)\end{array}$ & $\begin{array}{l}\text { OS_13 } \\
\text { OS_18 } \\
\text { OS_15 } \\
\text { OS_5 } \\
\text { OS_11 } \\
\text { OS_7 } \\
\text { OS_9 } \\
\text { OS_16 } \\
\text { OS_12 } \\
\text { OS_10 } \\
\text { OS_6 } \\
\text { OS_20 } \\
\text { OS_4 } \\
\text { OS_2 } \\
\text { OS_21 } \\
\text { OS_8 } \\
\text { OS_1 } \\
\text { OS_3 } \\
\text { OS_19 } \\
\text { OS_14 } \\
\text { OS_17 }\end{array}$ & $\begin{array}{l}0.859 \\
0.858 \\
0.858 \\
0.840 \\
0.824 \\
0.823 \\
0.822 \\
0.818 \\
0.804 \\
0.805 \\
0.789 \\
0.788 \\
0.784 \\
0.726 \\
0.744 \\
0.723 \\
0.691 \\
0.690 \\
0.657 \\
0.652 \\
0.633\end{array}$ & 0.974 & 0.650 & $\begin{array}{l}4.92 \\
4.97 \\
5.08 \\
4.91 \\
4.89 \\
4.93 \\
5.02 \\
4.94 \\
4.90 \\
4.87 \\
4.99 \\
5.17 \\
4.91 \\
4.88 \\
5.03 \\
4.85 \\
4.88 \\
5.03 \\
5.11 \\
5.04 \\
5.12 \\
\end{array}$ & $\begin{array}{l}1.117 \\
1.073 \\
1.043 \\
1.147 \\
1.181 \\
1.146 \\
1.103 \\
1.127 \\
1.144 \\
1.179 \\
1.100 \\
0.990 \\
1.150 \\
1.145 \\
0.998 \\
1.142 \\
1.169 \\
1.110 \\
0.907 \\
0.906 \\
1.201\end{array}$ \\
\hline $\begin{array}{l}\text { Competitive advantage } \\
(\alpha=0.949)\end{array}$ & $\begin{array}{l}\text { CA_3 } \\
\text { CA_4 } \\
\text { CA_2 } \\
\text { CA_1 } \\
\text { CA_8 } \\
\text { CA_7 } \\
\text { CA_5 } \\
\text { CA_6 } \\
\text { CA_10 } \\
\text { CA_9 }\end{array}$ & $\begin{array}{l}0.962 \\
0.952 \\
0.925 \\
0.904 \\
0.893 \\
0.870 \\
0.845 \\
0.841 \\
0.793 \\
0.766\end{array}$ & 0.974 & 0.650 & $\begin{array}{l}4.92 \\
4.94 \\
4.93 \\
4.93 \\
4.87 \\
4.81 \\
4.88 \\
4.74 \\
4.98 \\
5.06\end{array}$ & $\begin{array}{l}1.171 \\
1.158 \\
1.165 \\
1.170 \\
1.172 \\
1.214 \\
1.216 \\
1.209 \\
1.156 \\
1.177\end{array}$ \\
\hline
\end{tabular}

Table 3. HTMT.

\begin{tabular}{lccc}
\hline \multicolumn{1}{c}{ HTMT } & $\mathbf{1 .}$ & $\mathbf{2 .}$ & $\mathbf{3 .}$ \\
\hline 1. Competitive advantage & & & \\
2. Open innovation & 0.341 & & \\
3. Organizational strategy & 0.397 & 0.547 & \\
\hline
\end{tabular}

The measurement model is displayed in Figure 2. 


\subsection{Results of Structural Model Assessment}

For this purpose, the significance of the model was assessed based on path coefficients, $t$-values, and standard errors. The hypotheses tested the direct and indirect effects through the bootstrapping procedure using Smart PLS 3 [74]. The PLS algorithm followed by bootstrapping techniques were used to calculate the relative strength of each exogenous construct.

All hypotheses were significant according to Chin [71], who advocates a minimum structural coefficient of 0.2. As displayed in Table 4, open innovation had a significant and positive relationship with organizational strategy $(\beta=0.532, t=10.050 ; L L=0.426$, $\mathrm{UL}=0.625)$ and competitive advantage $(\beta=0.175, t=2.646$; $\mathrm{LL}=0.049, \mathrm{UL}=0.311)$; thus, $\mathrm{H} 1$ and $\mathrm{H} 3$ were supported because the lower limit and the upper limit included zero, indicating that this relationship was insignificant. Moreover, organizational strategy had a significant and positive relationship with competitive advantage $(\beta=0.289, t=4.011$; $\mathrm{LL}=0.160, \mathrm{UL}=0.437)$; thereby, $\mathrm{H} 2$ was supported.

Table 4. Path analysis: direct effects.

\begin{tabular}{ccccccrr}
\hline Hypotheses & $\begin{array}{c}\text { Original } \\
\text { Sample (O) }\end{array}$ & $\begin{array}{c}\text { Sample } \\
\text { Mean (M) }\end{array}$ & $\begin{array}{c}\text { Standard Error } \\
\text { (STERR) }\end{array}$ & $\begin{array}{c}\text { T Statistics } \\
\text { (O/STERR I) }\end{array}$ & L.L. & U.L. & Decision \\
\hline H1: OI -> OS & 0.532 & 0.533 & 0.053 & $10.050^{*}$ & 0.426 & 0.625 & Supported \\
H2: OS -> CA & 0.289 & 0.294 & 0.072 & $4.011^{*}$ & 0.160 & 0.437 & Supported \\
H3: OI -> CA & 0.175 & 0.177 & 0.066 & $2.646^{*}$ & 0.049 & 0.311 & Supported \\
\hline
\end{tabular}

Note: * $p<0.001$.

The significance of the mediating effect was tested using the Sobel test [76]. This test, considered valid for testing the statistical significance of the indirect effects, is widely used in recent research [77-79]. The Sobel test results [Sobel test statistic $=3.66623892(>1.96)$ ] confirm that organizational strategy mediates the relationship between open innovation and competitive advantage, as shown in Table 5.

Table 5. Sobel test (mediation test).

\begin{tabular}{|c|c|}
\hline Sobel Test & Values \\
\hline A (IV ßeta) & 0.532 \\
\hline B (DV ßeta) & 0.289 \\
\hline $\mathrm{SE}_{(\mathrm{A})}$ & 0.050 \\
\hline $\mathrm{SE}_{(\mathrm{B})}$ & 0.074 \\
\hline Sobel test statistic & $3.66623892(>1.96)$ \\
\hline One-tailed probability & $0.00012307(<0.05)$ \\
\hline Two-tailed probability & $0.0002961(<0.05)$ \\
\hline
\end{tabular}

We conclude also that open innovation justified $28.3 \%$ of organizational strategy $\left(R^{2}=0.283\right)$ and that organizational strategy justified $16.8 \%$ of competitive advantage $\left(\mathrm{R}^{2}=0.168\right)$.

The following figure (Figure 3) makes it possible to observe the structural research model assessment, already considering both direct and indirect effects. 
OS_1 OS_10 + OS_11 + OS_12 OS_13 OS_14 OS_15, OS_16 OS_17 OS_18 OS_19 OS_2 OS_20 OS_21

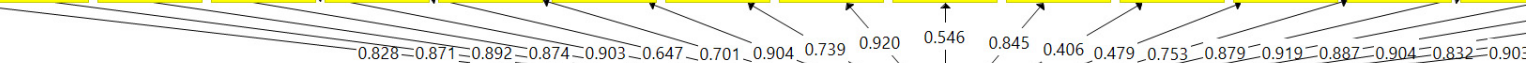

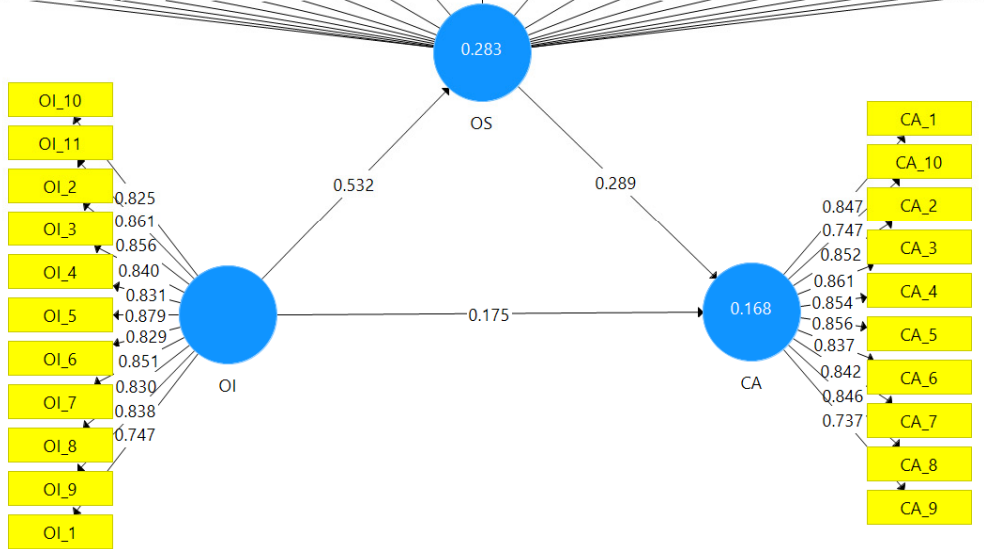

Figure 2. Measurement model assessment. Source: Own elaboration.

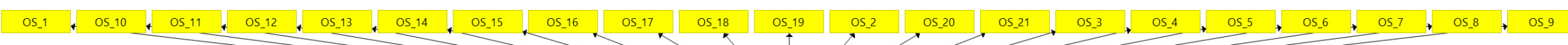

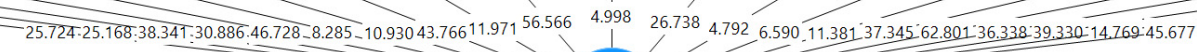

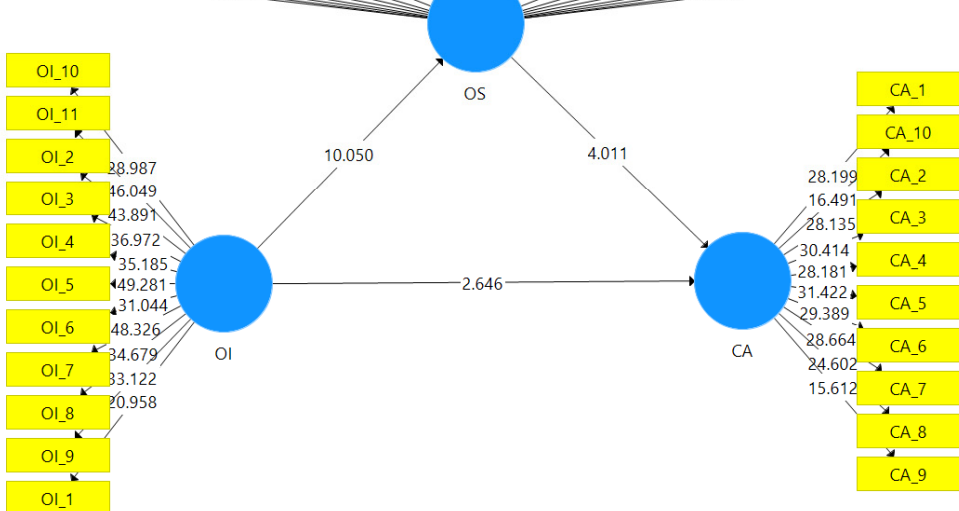

Figure 3. Structural model assessment. Source: Own elaboration. 


\section{Discussion and Conclusions}

Hypothesis 1 assesses the relationship between open innovation and organizational strategy. The results support it $(\beta=0.532 ; t=10.050 ; p<0.001)$. A blazing business model indicates the degree or intensity that organizational strategy may have as a competitive advantage to replicate that model by competitors. Therefore, the guiding element of the business model is the discovery of how to profit from innovation; new product development must be aligned with a business's model "go to market" and "value capture" strategies [80]. Business models contribute to the firm's value capture [80], namely in capturing the value of innovation [81] and in the search for a new paradigm of management innovation [6].

However, it is emphasized that identifying open innovation as an organizational strategy has been essential in discovering the risk factors to which organizations are subject. Chesbrough and Rosenbloom [81] state that a business model should (1) articulate the value proposition, (2) identify the market segment, (3) define the firm's value chain structure, (4) estimate the cost structure and profit potential, (5) describe the firm's position in the value network linking suppliers and customers, and (6) formulate the competitive strategy, through which the innovative firm will gain and maintain an advantage over rivals with structured communication channels and restricted access to important financial and operational information of the corporation.

Wendra et al. [18] state that technological innovation by itself does not guarantee economic success (of the firm), being necessary to discover how to share value with stakeholders and capture part of it so that, in this way, these values are indispensable in the design of a successful business model. The role of this model is based on its ability to transform ideas into profits. This scholar says that firms seeking innovation should not rely solely on internal knowledge, that is, they should not depend exclusively on the knowledge of their employees, but should go further by seeking external knowledge (partnerships). From this perspective, the employee is no longer the only essential part of the development of projects. There is now another fundamental part in this process, which is nurtured by the organizational collective knowledge.

The results also do not support hypothesis two, which analyzes the relationship between organizational strategy and competitive advantage $(\beta=0.289 ; t=4.011 ; p<0.001)$. In the face of the constantly evolving technological landscape, the firm's performance requires an organizational strategy to purposefully create, extend, or modify its resource base strategy. Therefore, the ability to sense the market, seize opportunities, and readjust or reconfigure portfolios of products/services or processes is essential for sustained competitive advantage [82]. On the other hand, for these authors, the lower ability of the top manager to sense and act in the face of an unstable market to create new emerging opportunities can cause strategic "insensitivity".

The results reinforce the paradigm described by Barney [40]. The firm's valuable, rare, imperfectly imitable, and non-substitutable resources are the cornerstone for strategies to achieve sustainable competitive advantages. Firms with dynamic strategic planning seek market opportunities in a constantly changing environment. Thus, sustainable planning allows firms to adjust their strategies to pursue environmental adaptations. However, nonadaptive planning may limit adjustments to the turbulence of the uncertain environment, and its formulation is central to achieving sustainable competitive advantage [83,84].

Understanding the main organizational capabilities, dimensions, and processes must contain a set of strategies that contribute to generating competitive advantages, which implies that the firm is transparent in using available resources. This process allows firms to optimize available resources for potential actions and thus meet changing environmental requirements. It enables the selection of strategic goals, which implies that companies prioritize the interests of the critical value of partners [85]. 
This strategy (of partnerships) helps minimize the loss of market leadership with key value-changing partners if a firm and its top managers cannot adequately manage their external environment. Shared responsibility implies that not only one individual (manager/leader) is responsible for failure in dealing with change, but the entire firm is responsible for failure or success [82]. Barney [40] maintains that planning is based on competitive advantage, flexibility, and the firm's ability to change uses new environmental opportunities/threats to emerge. Finally, strategy as a competitive advantage in SMEs [85], technological capability, strategic flexibility, product innovation [84], and resource-based view are valuable perspectives for strategic management research.

The results support the relationship between open innovation and competitive advantage, thus proving hypothesis 3 ( $\beta=0.175 ; t=2.646 ; p<0.001)$. In this sense, open innovation requires identifying and understanding (emerging) technologies to expand its technological knowledge base to maintain cutting-edge technology, which is essential for creating competitive advantage [86]. The acquisition of external technologies is crucial for a firm in a complex environment, and it enables it to eliminate firm inertia and capture the value of entrepreneurial capability [87]. On the other hand, a firm depends on existing market knowledge (external) and technological knowledge (internal) to fulfill organizational goals and objectives. Therefore, management innovation allows the firm to introduce new or improved products before its competitors, thus thriving and creating competitive advantages [88].

For Bao et al. [89], innovation in products and services creates value for organizations and consumers. In turn, this connection can lead to a long-lasting relationship between stakeholders. This theoretical contribution meets what is stated by [86] when they show that innovation increases competitive advantages in organizations in the external factors (e.g., partnerships) that influence and amplify innovation in SMEs. This linkage between stakeholders and positive outcomes for the organization promotes the growth of the entire regional and national economy [87]. The maintenance of a firm's market position, requiring it to possess financial, organizational, and relationship capacities, has a significant and positive contribution to gaining a competitive advantage [87].

Hypothesis four, which examines the mediating effect of organizational strategy on the relationship between open innovation and competitive advantage, is supported ( $\beta=0.154$; $t=3.691 ; p<0.001$ ). Innovation can be a key driver of competitiveness. Still, it can also be risky and create uncertainty [88], and open innovation is a strategy that firms use to create a competitive advantage by introducing superior, cheaper, and faster services [6]. For Goksoy et al. [88], the business environment is highly dynamic. Organizations need to develop new competitive advantages to keep up with the speed of technology changes in customer demands and global competition. The strategy enables the organization to create competition in the long run by bringing together knowledge, skills in technology, experience in creativity, development by introducing new ideas in product innovation, process innovation, or business model innovation. This perspective brings positive results and promotes the entire regional and national economy [90]. Porter $[46,47]$ states that the components of competitive advantage originate in a firm's ability to maximize the efficiency of its production process. The positive effect confirmed in this hypothesis thus relates to (1) competitive advantage $[45,86,88,91]$, (2) technology acquisition as capturing firm value [87], and (3) organizational strategy with the theory of open innovation, diversity, and divergence [92].

\section{Implications}

\subsection{Theoretical Implications}

This study provides a theoretical framework for understanding the relationships between four constructs (open innovation, organizational strategy, and competitive advantage) in the Portuguese hospitality sector, so far not exploited by scholars.

This research was developed based on the conceptual model proposed by Chesbrough [6] for a better knowledge of the relationship between open innovation, corporate 
risk, organizational strategy, and management mechanisms, with the following contributions. First, the model understands using different measurement scales to validate it with more robust measurement instruments for analysis. This study analyzes in-depth the psychometric properties of all latent variables of the structural model (PLS-SEM), representing the differentiated paths between endogenous and exogenous constructs. Second, the role of the open innovation model was emphasized, in the proportion in which it can potentiate or influence the attraction of resources necessary for the development of the hospitality sector activity, namely organizational and technological resources. Thus, we consider that this research allows us to fill the existing gaps in the literature.

\subsection{Practical Implications}

The results of this study contribute to the development of new instruments and programs to support SMEs. By identifying resources, technologies, and dynamic capabilities that influence competitive advantage, directly or indirectly, this study is beneficial for top managers by stimulating entrepreneurial behavior, consubstantiating a factor of raising resources and capabilities needed by the firm and the involvement of other sectors of the economy, because the hospitality sector has proved vital for improving the performance of firms in Portugal.

The relationship between the constructs will allow top managers to strengthen corporate resources and capabilities, thus promoting entrepreneurial policies that boost the relationship between open innovation and competitive advantage. Finally, this study will allow governments (national, regional, and local) to create policies, programs, and incentives to deepen the open innovation model, thus promoting the exchange of internal knowledge with the external, thus strengthening the dynamics of the business ecosystem.

\section{Limitations and the Future Directions}

Some limitations stand out in the course of this scientific study. First, it refers to the survey. We have chosen to apply this one to firms whose e-mail address was registered on the AHRESP's database. Although the number of firms' responses is considered significant (251), we believe that a more comprehensive sample would allow a more refined analysis of the results. Besides, it is a non-probabilistic sample for convenience. Second, we choose only executive hotel directors, and the survey does not characterize whether this top manager has responded to it. We also understand that evaluating the different constructs of this study based on a single person's opinion (hotel executive director) may not reflect the firm's reality since the decisions made by a team may have different views about the studied activity.

Author Contributions: All authors contributed to the research design and implementation, to the analysis of the results, and the writing and revision of the manuscript. All authors have read and agreed to the published version of the manuscript.

Funding: Cátedra Telefónica, Aula Smatcities (Telefónica Chair) Universitat Rovira i Virgili, Universitat de Barcelona on Smartcities.

Institutional Review Board Statement: Not applicable.

Informed Consent Statement: Informed consent was obtained from all subjects involved in the study.

Data Availability Statement: The data presented in this study is available on request from the corresponding author. The data are not publicly available due to privacy of data sources.

Acknowledgments: The authors acknowledge the highly valuable comments and suggestions provided by the editors and reviewers, which contributed to the improvement in the clarity, focus, contribution, and scientific soundness of the current study.

Conflicts of Interest: The authors declare that there are no conflicts of interest. 


\section{Appendix A. Questionnaire}

\section{Appendix A.1. Open Innovation}

Appendix A.1.1. Inbound Open Innovation

(seven-point scale: 1 = "strongly disagree" and 7 = "strongly agree").

OI1. Constantly scan the external environment for inputs such as technology, information, ideas, knowledge, etc.

OI2. Actively seek out external sources (e.g., research groups, universities, suppliers, customers, and competitors, etc.) of knowledge and technology when developing new products.

OI3. Believe it is good to use external sources (e.g., research groups, universities, suppliers, customers, and competitors, etc.) to complement our own R\&D.

OI4. Often bring in externally developed knowledge and technology to use in conjunction with our own R\&D.

OI5. Seek out technologies and patents from other firms, research groups, or universities. OI6. purchase external intellectual property to use in our own R\&D.

\section{Appendix A.1.2. Outbound Open Innovation}

(seven-point scale: 1 = "strongly disagree" and 7 = "strongly agree").

OI7. External partners, such as customers, competitors, research institutes, consultants, suppliers, government, or universities are directly involved in all our innovation projects.

OI8. All our innovation projects are highly dependent upon the contribution of external partners, such as customers, competitors, research institutes, consultants, suppliers, government, or universities.

OI9. Our firm often buys R\&D-related services from external partners, such as customers, competitors, research institutes, consultants, suppliers, government, or universities.

OI10. Our firm often buys intellectual property, such as patents, copyrights, or trademarks, from external partners to be used in our innovation projects.

OI11. Our firm invests in other firms because we would like to obtain synergies that are beneficial to our innovation projects.

Sources: [61,62].

Appendix A.2. Organizational Strategy

(seven-point scale: 1 = "strongly disagree" and 7 = "strongly agree").

Appendix A.2.1. The Environmental Dynamism Scale

Table A1. The Environmental Dynamism Scale.

\begin{tabular}{|c|c|c|}
\hline $\begin{array}{l}\text { OS1. Our business unit must rarely change its } \\
\text { marketing practices to keep up with the market } \\
\text { and competitors }\end{array}$ & $1-2-3-4-5-6-7$ & $\begin{array}{l}\text { Our business unit must change its marketing } \\
\text { practices extremely frequently } \\
\text { (e.g., semiannually) }\end{array}$ \\
\hline $\begin{array}{l}\text { OS2. The rate at which products/services are } \\
\text { getting obsolete in the industry is very slow (e.g., } \\
\text { basic metal like semiconductors) }\end{array}$ & $1-2-3-4-5-6-7$ & $\begin{array}{l}\text { The rate of obsolescence is very high (as in some } \\
\text { fashion goods and copper) }\end{array}$ \\
\hline $\begin{array}{l}\text { OS3. Actions of competitors are quite easy to } \\
\text { predict (as in some basic industries) }\end{array}$ & $1-2-3-4-5-6-7$ & The actions of competitors are unpredictable \\
\hline $\begin{array}{l}\text { OS4. Demand and consumer tastes are fairly } \\
\text { easy to forecast (e.g., for milk companies) }\end{array}$ & $1-2-3-4-5-6-7$ & $\begin{array}{l}\text { Demand and tastes are almost unpredictable } \\
\text { (e.g., high-fashion goods) }\end{array}$ \\
\hline $\begin{array}{l}\text { OS5. The production/service technology is not } \\
\text { subject to very much change and is well } \\
\text { established (e.g., in steel production) }\end{array}$ & $1-2-3-4-5-6-7$ & $\begin{array}{l}\text { The modes of production/service change often } \\
\text { and in a major way (e.g., advanced } \\
\text { electronic components) }\end{array}$ \\
\hline
\end{tabular}




\section{Appendix A.2.2. The Organization Structure Scale}

Table A2. The Organization Structure Scale.

In general, the operating management philosophy in my firm favors ...

OS6. Highly structured channels of communication and highly restricted access to important financial and operating information

$1-2-3-4-5-6-7$

OS7. A strong insistence on a uniform managerial style throughout the firm

$1-2-3-4-5-6-7$

$1-2-3-4-5-6-7$

OS8. A strong emphasis on giving the most to say in decision making to formal line managers

OS9. A strong emphasis on holding fast to tried and true management principles despite any changes in business conditions

$1-2-3-4-5-6-7$

Open channels of communication with important financial and operating information flowing quite freely throughout the organization

Managers' operating styles ranging freely, from the very formal to the very informal

A strong tendency to let the expert in a given situation have the most say in decision making even if this means temporary bypassing of formal lines of authority

A strong emphasis on adapting freely to changing circumstances without too much concern for past practice

OS10. A strong emphasis on always getting

personnel to follow the formally laid

$1-2-3-4-5-6-7$ down procedures

OS11. Tight formal control of most operations by means of sophisticated control and information systems

$1-2-3-4-5-6-7$

A strong emphasis on getting things done even if this means disregarding formal procedures

Loose, informal control; heavy dependence on informal relationships and norm of cooperation for getting work done

A strong tendency to let the requirements of the

OS12. A strong emphasis on getting line and staff personnel to adhere closely to formal job descriptions
$1-2-3-4-5-6-7$ proper on-job behavior

Appendix A.2.3. The Strategic Posture Scale

Table A3. The Strategic Posture Scale.

In general, the top managers of my firm favor...

OS13. A strong emphasis on the marketing of tried and true products or services

$1-2-3-4-5-6-7$

A strong emphasis on $R \& D$, technological leadership and innovation

How many new lines of products or services has your firm marketed in the past five years (or since its establishment)?

\begin{tabular}{lll}
\hline OS14. No new lines of products or service & $1-2-3-4-5-6-7$ & Many new lines of products or services \\
\hline $\begin{array}{l}\text { OS15. Changes in product or service line have been } \\
\text { mostly of a minor nature }\end{array}$ & $1-2-3-4-5-6-7$ & $\begin{array}{l}\text { Changes in product or service line have usually been } \\
\text { quite dramatic }\end{array}$ \\
\hline
\end{tabular}

In dealing with its competitors, my firm ....

OS16. Typically responds to actions which competitors initiate

OS17. Is very seldom the first business to introduce new products/services, administrative techniques, or operating technologies, etc.

OS18. Typically seeks to avoid competitive clashes, preferring a "live-and-let-live" posture

In general, the top managers of my firm have...

OS19. A strong proclivity for low-risk risk projects (with normal and certain rates of return)
1-2-3-4-5-6-7

Typically initiates actions which competitors than respond to

Is very often the first business to introduce new

1-2-3-4-5-6-7 products/services, administrative techniques, or operating technologies, etc.

Typically adopts a very competitive, "undo-the-competitors" posture

In general, the top managers of my firm believe that ...

OS20. Owing to the nature of the environment, it is best to explore it gradually via timid, incremental behavior very high returns)

1-2-3-4-5-6-7

Owing to the nature of the environment, bold, wide-ranging acts are necessary to achieve the firm's objectives 
Table A3. Cont.

\begin{tabular}{ll}
\hline When confronted with decision-making situations involving uncertainty, my firm ... \\
\hline $\begin{array}{l}\text { OS21. Typically adopts a cautious, wait-and-see } \\
\text { posture in order to minimize the probability of } \\
\text { making costly decisions }\end{array}$ & $\begin{array}{l}\text { Typically adopts a bold, aggressive posture in order } \\
\text { to maximize the probability of exploiting potential } \\
\text { opportunities }\end{array}$ \\
\hline
\end{tabular}

Source: [63].

Appendix A.3. Competitive Advantage

(seven-point scale: 1 = "much worse" and 7 = "much better").

Appendix A.3.1. Cost

CA1: Production cost per unit.

CA2: Cost of goods sold.

CA3: Selling price to end-users overseas.

Appendix A.3.2. Service

CA4: Product accessibility.

CA5: Technical support/after-sales service.

CA6: Delivery speed and reliability.

CA7: Product line breadth.

Appendix A.3.3. Product

CA8: Product quality.

CA9: Packaging.

CA10: Design and style.

Source: [64].

\section{References}

1. Lee, S.; Park, G.; Yoon, J.; Park, J. Open innovation in SMEs: An intermediated network model. Res. Policy 2010, 39, $290-300$. [CrossRef]

2. Huizingh, E.K. Open innovation: State of the art and future perspectives. Technovation 2011, 31, 2-9. [CrossRef]

3. Aranha, E.A.; Garcia, N.A.P.; Silva, G.N.R.; Santos, P. Open Innovation and Business Model in Brazilian Small Business. Int. J. Bus. Manag. Econ. Res. 2017, 8, 1008-1015.

4. Smith, W. Dynamic decision making: A model of senior leaders managing strategic paradoxes. Acad. Manag. J. 2014, 37, 1592-1623. [CrossRef]

5. Ferreira, J.L.M.; Teixeira, A.A.C. Open innovation and knowledge for fostering business ecosystems. J. Innov. Know. 2018, 4, 253-255. [CrossRef]

6. Chesbrough, H.W. The era of open innovation. MIT Sloan Manag. Rev. 2003, 44, 35-41.

7. Finkelstein, S.; Hambrick, D.C.; Cannella, A.A. Strategic Leadership: Theory and Research on Executives, Top Management Teams, and Boards; Oxford University Press: New York, NY, USA, 2009.

8. Diaz-Fernandez, M.; Bornay-Barrachina, M.; Lopez-Cabrales, A. Innovation and firm performance: The role of human resource management practices. In Evidence-Based HRM: A Global Forum for Empirical Scholarship; Emerald Group Publishing Limited: Bingley, UK, 2015; pp. 64-80.

9. Chesbrough, H.W.; Crowther, A.K. Beyond high tech: Early adopters of open innovation in other industries. RED Manag. 2006, 36, 229-236.

10. Crescenzi, R.; Nathan, M.; Rodríguez-Pose, A. Do inventors talk to strangers? On proximity and collaborative knowledge creation. Res. Policy 2016, 45, 177-194. [CrossRef]

11. Shearmur, R.; Doloreux, D. How open innovation processes vary between urban and remote environments: Slow innovators, market-sourced information and frequency of interaction. Entrep. Reg. Dev. 2016, 28, 337-357. [CrossRef]

12. Alavi, M.; Leidner, D.E. Review: Knowledge management and knowledge management systems: Conceptual foundations and research issues. MIS Q. 2001, 25, 107-133. [CrossRef]

13. West, J.; Salter, A.; Vanheverbeke, W.; Chesbrough, H. Open innovation: The next decade. Res. Policy 2014, 43, 805-811. [CrossRef]

14. Martins, S.O.; Lino, J.A. Influência das Práticas de Inovação Aberta na Prospecção de Conhecimentos para a Criação de Valor em Ambientes de Alta Complexidade sob Condições de Incerteza e Imprevisibilidade. Rev. Adm. Inovação 2014, 11, $295-318$.

15. Lião, Y.-W.; Wang, Y.-M.; Tu, Y.-M. Understanding the dynamics between organizational IT investment strategy and market performance: A system dynamics approach. Comput. Ind. 2015, 71, 46-57. 
16. Fayoumi, A.; Loucopoulos, P. Conceptual modeling for the design of intelligent and emergent information systems. Expert Syst. Appl. 2016, 59, 174-194. [CrossRef]

17. Wendra, W.; Sule, E.T.; Joeliaty, J.; Azis, Y. Exploring dynamic capabilities, intellectual capital and innovation performance relationship: Evidence from the garment manufacturing. Bus. Theory Pract. 2019, 20, 123-136. [CrossRef]

18. Chesbrough, H.W. Open Innovation: The New Imperative for Creating and Profiting from Technology; Harvard Business School Press: Boston, MA, USA, 2003; pp. 1-10.

19. Weiblen, T. The open business model: Understanding an emergent concept. J. Multi Bus. Model Innov. Technol. 2014, 2, 35-66. [CrossRef]

20. Lopez-Cabrales, A.; Bornay-Barrachina, M.; Diaz-Fernandez, M. Leadership and dynamic capabilities: The role of HR systems. Pers. Rev. 2015, 46, 255-276. [CrossRef]

21. Appleyard, M.M.; Chesbrough, H. The Dynamics of Open Strategy: From Adoption to Reversion. Long Range Plan. 2017, 50, 310-321. [CrossRef]

22. Chesbrough, H.W.; Bogers, M. Explicating open innovation: Clarifying an emerging paradigm for understanding innovation. In New Frontiers in Open Innovation; Chesbrough, H., Vanhaverbeke, W., West, J., Eds.; Oxford University Press: Oxford, UK, 2014; pp. 3-28.

23. Cohen, W.M.; Levinthal, D.A. Absorptive Capacity: A New Perspective on Learning and Innovation. Adm. Sci. Q. 1990, 35, 128-152. [CrossRef]

24. Teece, D.J.; Pisano, G.; Shue, A. Dynamic capabilities and strategic management. Strateg. Manag. J. 1997, 18, 509-533. [CrossRef]

25. Lichtenthaler, U. Open innovation: Past research, current debates, and future directions. Acad. Manag. Perspect. 2011, $25,75-93$.

26. Chesbrough, H.W. Open innovation: Where we've been and where we're going. Res.-Technol. Manag. 2012, 55, 20-27. [CrossRef]

27. Kulkarni, U.; Robles-Flores, J.A.; Popovič, A. Business intelligence capability: The effect of top management and the mediating roles of user participation and analytical decision making orientation. J. Assoc. Infor. Sys. 2017, 18, 516-541. [CrossRef]

28. Van De Vrande, V.; De Jong, J.P.J.; Vanhaverbeke, W.; De Rochemont, M. Open innovation in sme's: Trends, motives and management challenges. Technovation 2009, 29, 423-437. [CrossRef]

29. Erdil, T.S.; Özdemir, O. The Determinants of Relationship between Marketing Mix Strategy and Drivers of Export Performance in Foreign Markets: An Application on Turkish Clothing Industry. Proc. Soc. Behav. Sci. 2016, 235, 546-556. [CrossRef]

30. Ostos, J.; Hinderer, H.; Bravo, E. Relationship between the Business Environment and Business Strategy Types: Evidence in Peruvian Companies. Univ. Empresa 2016, 19, 65-86.

31. Wheelen, T.L.; Hunger, J.D.; Hoffman, A.N.; Bamford, C.E. Strategic Management and Business Policy: Globalization, Innovation, and Sustainability; Pearson: London, UK, 2015.

32. Wijethilake, C.; Munir, R.; Appuhami, R. Environmental Innovation Strategy and Organizational Performance: Enabling and Controlling Uses of Management Control Systems. J. Bus. Ethis 2018, 151, 1139-1160. [CrossRef]

33. Huo, B.; Qi, Y.; Wang, Z.; Zhao, X. The impact of supply chain integration on firm performance: The moderating role of competitive strategy. Supply Chain Manag. 2014, 23, 552-564. [CrossRef]

34. Kaše, R.; Škerlavaj, M. Non-technological innovation research: Evaluating the intellectual structure and prospects of an emerging field. Scand. J. Manag. 2016, 32, 69-85.

35. Roland, J.O.; Schoormans, J.P.L. The pattern of development and diffusion of breakthrough communication technologies. Eur. J. Innov. Manag. 2014, 7, 292-302.

36. Balodi, K.C. Strategic Orientation and Organizational Forms: An Integrative Framework. Eur. Bus. Rev. 2014, 26, 188-203. [CrossRef]

37. Spyropoulou, S.; Katsikeas, C.S.; Skarmeas, D.; Morgan, N.A. Strategic goal accomplishment in export ventures: The role of capabilities, knowledge. e environment. J. Acad. Mark. Sci. 2018, 46, 109-130. [CrossRef]

38. Oyewobi, L.; Windapo, A.; Rotimi, J.; Jimoh, R. Relationship between competitive strategy and construction organization performance. Manag. Decision 2016, 54, 2340-2366. [CrossRef]

39. Lita, R.P.; Meuthia, F.R.F. SME's Performance of Creative Industries Supporting Tourism In Indonesia: Market Orientation, Learning Orientation and Organizational Innovativeness As Determinants. Acad. Mark. Stud. J. 2018, 22, 1-18.

40. Barney, J. Firm Resources and Sustained Competitive Advantage. J. Manag. 1991, 17, 99-120. [CrossRef]

41. Rua, O.L.; França, A.; Fernández, R.O. Key drivers of SMEs export performance: The mediating effect of competitive advantage. J. Knowl. Manag. 2018, 22, 257-270. [CrossRef]

42. Rua, O. Absorptive Capabilities and Competitive Advantage: The Linkage. Period. Polytech. Soc. Manag. Sci. 2019, 27, 164-172. [CrossRef]

43. Knabke, T.; Olbrich, S. Building novel capabilities to enable business intelligence agility: Results from a quantitative study. Inf. Syst. e-Bus. Manag. 2018, 16, 493-546. [CrossRef]

44. Nuryakin, M. Competitive advantage. and product innovation key sucesso of batik sme's marketing performance in Indonesia. Acad. Strateg. Manag. 2018, 17, 1-17.

45. Porter, M.E. Competitive Advantage; Free Press: New York, NY, USA, 1985.

46. Porter, M.E. Competitive Advantage of Nations; Free Press: New York, NY, USA, 1990.

47. Porter, M.E. Industrial organization and the evolution of concepts for strategic planning: The new learning. Manag. Decis. Econ. 1990, 3, 172-180. [CrossRef] 
48. Barney, J.B. Resource-based theories of competitive advantage: A tenyear retrospective on the resource-based view. J. Manag. 2001, 27, 643-650. [CrossRef]

49. Rua, O.L. Linking intangible resources and competitive advantage. In Handbook of Research on Corporate Restructuring and Globalization; Moreira, A.C., Silva, P., Eds.; IGI Global: Hershey, PA, USA, 2019; pp. 3017-3321.

50. Bilińska-Reformat, K.; Kucharska, B.; Twardzik, M.; Dolega, L. Sustainable development concept and creation of innovative business models by retail chains. Int. J. Retail. Distrib. Manag. 2019, 47, 2-18. [CrossRef]

51. Rua, O.L. Contributions of entrepreneurial orientation to competitive advantage: The Portuguese experience of the textile SMEs. In Entrepreneurial Orientation and Opportunities for Global Economic Growth; Rua, O.L., Ed.; IGI Global: Hershey, PA, USA, 2019; pp. 136-153.

52. Simão, L.; Franco, M. External knowledge sources as antecedents of organizational innovation in firm workplaces: A knowledgebased perspective. J. Knowl. Manag. 2018, 22, 237-256. [CrossRef]

53. Hong, J.F.L.; Zhao, X.; Stanley, S.R. Collaborative-based HRM practices and open innovation: A conceptual review. Int. J. Hum. Resour. Manag. 2019, 30, 31-62. [CrossRef]

54. Auh, S.; Menguc, B. Balancing exploration and exploitation: The moderating role of competitive intensity. J. Bus. Res. 2005, 58, 1652-1661. [CrossRef]

55. Tsai, K.-H.; Yang, S.-Y. Firm innovativeness and business performance: The joint moderating effects of market turbulence and competition. Ind. Market. Manag. 2013, 43, 1279-1294. [CrossRef]

56. Rua, O.L.; Ferreira, A. Predictive strategic factors in export performance in automotive industry: The mediating effect of innovation. In Cases on Internationalization Challenges for SMEs; Moreira, A.C., Ed.; IGI Global: Hershey, PA, USA, 2020; pp. 239-260.

57. Wang, F.K.; Wu, H. Service strategies of small cloud service providers: A case study of a small cloud service provider and its clients in Taiwan. Int. J. Inf. Manag. 2014, 34, 406-415. [CrossRef]

58. Krejcie, R.V.; Morgan, D.W. Determining Sample Size for Research Activities. Educ. Psychol. Meas. 1970, 30, 607-610. [CrossRef]

59. Menon, A.; Bharadwaj, S.G.; Adidam, P.T.; Edison, S.W. Antecedents and consequences of marketing strategy making: A model and a test. J. Mark. 1999, 63, 18-40. [CrossRef]

60. Hair, J.; Hult, G.T.M.; Ringle, C.; Sarstedt, M. A Primer on Partial Least Squares Structural Equation Modeling (PLS-SEM); Sage: London, UK, 2016.

61. Sisodiya, S.R.; Johnson, J.L.; Grégoire, Y. Inbound open innovation for enhanced performance: Enablers and opportunities. Ind. Mark. Manag. 2013, 42, 836-849. [CrossRef]

62. Cheng, C.C.J.; Huizingh, E.K.R.E. When Is Open Innovation Beneficial? The Role of Strategic Orientation. J. Prod. Innov. Manag. 2014, 31, 1235-1253. [CrossRef]

63. Morgan, P.M.; Jeffrey, G.C.; Michael, B.H. The Relationship between Environmental Dynamism and Small Firm Structure, Strategy, and Performance. Journal of Marketing Theory and Practice. Mark. Entrep. Interface 2000, 8, 63-78.

64. Kaleka, A. Resources and capabilities driving competitive advantage in export markets: Guidelines for industrial exports. Ind. Mark. Manag. 2002, 31, 273-283. [CrossRef]

65. Brislin, R.W. Back-translation for cross-cultural research. J. Cross-Cult. Psychol. 1971, 1, 185-216. [CrossRef]

66. Armstrong, J.S.; Overton, T.S. Estimating nonresponse bias in mail surveys. J. Mark. Res. 1977, 14, 2396-2402. [CrossRef]

67. Pestana, M.H.; Gageiro, J.N. Análise de Dados para Ciências Socais: A Complementaridade do SPSS, 5th ed.; Edições Sílabo: Lisboa, Portugal, 2010.

68. Sarstedt, M.; Ringle, C.M.; Smith, D.; Reams, R.; Hair, J.F. Partial Least Squares Structural Equation Modeling (PLS-SEM): A Useful Tool for Family Business Researchers. J. Fam. Bus. Strategy 2014, 5, 105-115. [CrossRef]

69. Nunnally, J.C. Psychometric Theory, 2nd ed.; McGraw-Hill: New York, NY, USA, 1978.

70. Chin, W.W. How to write up and report PLS analyses. In Handbook of Partial Least Squares: Concepts, Methods and Applications in Marketing and Related Fields; Vinzi, V.E., Chin, W.W., Henseler, J., Wang, H., Eds.; Springer: Berlin/Heidelberg, Germany, 2010; pp. 655-690.

71. Chin, W.W. The Partial Least Squares approach to structural equation modelling. In Modern Methods for Business Research; Marcoulides, G.A., Ed.; Lawrence Erlbaum Associates Publisher: Mahwah, NJ, USA, 1998; pp. 295-336.

72. Gefen, D.; Straub, D. A practical guide to factorial validity using PLS-graph: Tutorial and annotated example. Commun. Assoc. Inf. Syst. 2005, 16, 91-109. [CrossRef]

73. Fornell, C.; Larcker, D. Evaluating structural equation models with unobserved variables and measurement error. J. Mark. Res. 1981, 18, 39-50. [CrossRef]

74. Henseler, J.; Ringle, C.M.; Sarstedt, M. A new criterion for assessing discriminant validity in variance-based structural equation modeling. J. Acad. Mark. Sci. 2015, 43, 115-135. [CrossRef]

75. Gold, A.H.; Malhotra, A.; Segars, A.H. Knowledge management: An organizational capabilities perspective. J. Manag. Inform. Sys. 2001, 18, 185-214. [CrossRef]

76. Sobel, M.E. Asymptotic confidence intervals for indirect effects in structural equation models. In Sociological Methodology; Leinhart, S.S., Ed.; Jossey-Bass: San Francisco, CA, USA, 1982; pp. 290-312.

77. Preacher, J.K.; Hayes, A.F. Asymptotic and resampling strategies for assessing and comparing indirect effects in multiple mediator models. Behav. Res. Methods 2008, 40, 879-891. [CrossRef] [PubMed] 
78. Yunis, M.; El-Kassar, A.-N.; Tarhini, A. Impact of ICT-based innovations on organizational performance: The role of corporate entrepreneurship. J. Enterp. Inf. Manag. 2017, 30, 122-141. [CrossRef]

79. Parawansa, S.; Anggraece, D. Effect of commitment and customers' satisfaction on the relationship between service quality and customer retention in rural banks in Makassar, Indonesia. J. Manag. Dev. 2018, 37, 53-64. [CrossRef]

80. Denicolai, S.; Ramirez, M.; Tidd, J. Creating and capturing value form external knowledge: The moderating role of knowledge intensity. RED Manag. 2014, 44, 248-264.

81. Chesbrough, H.W.; Rosenbloom, R.S. The Role of the Business Model in Capturing Value from Innovation: Evidence from Xerox Corporation's Technology Spin-Off Companies. Ind. Corp. Chang. 2002, 11, 529-555. [CrossRef]

82. Ojha, D.; Patel, P.C.; Sridharan, S.V. Dynamic strategic planning and firm competitive performance: A conceptualization and an empirical test. Int. J. Prod. Econ. 2020, 222, 107509. [CrossRef]

83. Doz, Y.; Kossonen, M. The Dynamics of Strategic Agility: Nokia's Rollercoaster Experience. Calif. Rev. Manag. 2008, 50, 95-118. [CrossRef]

84. Priem, R.L.; Butler, J.R. Is the Resource-Based "View" a Useful Perspective for Strategic Management Research? Acad. Manag. Rev. 2001, 26, 22-40.

85. Giannoni, C.; Alarcón, L.F.; Vera, S. Strategic leadership and organizational learning. Acad. Manag. Rev. 2018, 29, $222-240$.

86. Distamont, A.; Khongmalai, O.; Rassameethes, R.; Distanont, S. Collaborative triangle for effective community water resource management in Thailand. Kasetsart J. Soc. Sci. 2018, 39, 374-380. [CrossRef]

87. Lichtenthaler, U. Intellectual property and open innovation: An empirical analysis. Int. J. Technol. Manag. 2010, 52, 372-391. [CrossRef]

88. Goksoy, A.; Vayvay, O.; Ergeneli, N. Gaining competitive advantage through innovation strategies: An application in warehouse management processes. Am. J. Bus. Manag. 2013, 2, 304-321.

89. Bao, Y.; Ilmudeen, A.; Alharbi, I.M.; Zubair, N. Revisiting dynamic capability for organizations' innovation types Does it matter for organizational performance in China? Eur. J. Innov. Manag. 2021, 24, 507-532.

90. Calabretta, G.; Gemser, G.; Wijnberg, N.M. The Interplay between Intuition and Rationality in Strategic Decision Making: A Paradox Perspective. Organ. Stud. 2017, 38, 365-401. [CrossRef]

91. Opoku, A.; Ahmed, V.; Akotia, J. Choosing an Appropriate Research Method. In Research Methodology in the Built Environment; Ahmed, V., Opoku, A., Aziz, Z., Eds.; Routledge: London, UK, 2016; pp. 32-49.

92. Chesbrough, H.W.; Appleyard, M.M. Open innovation and strategy. Calif. Manag. Rev. 2007, 50, 57-76. [CrossRef] 